\title{
Philometrid nematodes infecting fishes from the Everglades National Park, Florida, USA, with description of two new species
}

\author{
František Moravec $^{1}$ and Micah Bakenhaster ${ }^{2}$ \\ ${ }^{1}$ Institute of Parasitology, Biology Centre of the Academy of Sciences of the Czech Republic, Branišovská 31, 37005 České \\ Budějovice, Czech Republic; \\ ${ }^{2}$ Fish and Wildlife Research Institute, Florida Fish and Wildlife Conservation Commission, 100 Eighth Avenue Southeast, \\ St. Petersburg, Florida 33701, USA
}

\begin{abstract}
The following three species of the Philometridae (Nematoda: Dracunculoidea) are described from marine perciform fishes of the Everglades National Park (northern Gulf of Mexico), Florida, USA: Philometra brevispicula sp. n. (male and females) from the subcutaneous tissue of mouth of the gray snapper Lutjanus griseus (Linnaeus) (Lutjanidae), Philometroides grandipapillatus sp. n. (only females) from pectoral fin muscle of the crevalle jack Caranx hippos (Linnaeus) (Carangidae), and Caranginema americanum Moravec, Montoya-Mendoza et Salgado-Maldonado, 2008 (females) from the subcutaneous fascia of trunk muscle in crevalle jack C. hippos. Philometra brevispicula is mainly characterized by small cephalic papillae of the external circle, the absence of oesophageal teeth and the presence of small caudal projections in gravid female, markedly short spicules ( $45 \mu \mathrm{m})$ in male, and by its location in the host. Philometroides grandipapillatus differs from congeners mainly in the shape of the cephalic region (narrow, conspicuously protruding), large cephalic papillae of the external circle and the absence of caudal projections in female, and by the site of infection in the host. Caranginema americanum is for the first time recorded from the northern Gulf of Mexico.
\end{abstract}

Keywords: parasitic nematode, Philometra, Philometroides, Caranginema, marine fish, Lutjanus, Caranx, Florida, Gulf of Mexico

Philometrid nematodes (Philometridae) are usually pathogenic parasites occurring frequently in commercially important wild or cultured fish hosts (Moravec 2006). Due to some morphological and biological peculiarities, most of them are known only by their large-sized females. The knowledge of the fauna of these nematodes parasitizing marine and brackish-water fishes in the western North Atlantic remains fragmentary. To date, a total of 19 nominal species of these parasites (14 of Philometra Costa, 1845, 2 of Philometroides Yamaguti, 1935, 1 of Spirophilometra Parukhin, 1971, 1 of Dentiphilometra González-Solís, Moravec et Tuz Paredes, 2007 and 1 of Caranginema Moravec, Montoya-Mendoza et SalgadoMaldonado, 2008) have been reported from this region (Moravec 2006, González-Solís et al. 2007, Moravec and Salgado-Maldonado 2007, Moravec et al. 2007, 2008a,b, 2010, Moravec and de Buron 2009a,b, Moravec and Bakenhaster 2010), but records of some of them are probably based on misidentifications (see Petter and Radujković 1989, Moravec 2006).

During recent helminthological investigations of some marine fishes in the Everglades National Park, Florida, USA (northern Gulf of Mexico), two new and one littleknown species of philometrid were found in two species of perciform fishes, the gray snapper Lutjanus griseus (Linnaeus) (Lutjanidae) and the crevalle jack Caranx hippos (Linnaeus) (Carangidae). They are described herein. Both the gray snapper and the crevalle jack are subtropical, reef-associated fishes occupying overlapping habitats and ranges (Froese and Pauly 2010). They both occur in seawater and brackish-water (including a range of habitats from coastal rivers to offshore reefs. Gray snapper is distributed in the western Atlantic from Massachusetts, USA and Bermuda southward to Rio de Janeiro, Brazil, including West Indies, Gulf of Mexico and the Caribbean Sea, whereas the crevalle jack occurs in the western Atlantic from Nova Scotia, Canada and northern Gulf of Mexico to Uruguay, including the Greater Antilles, and in the eastern Atlantic from Portugal to Angola, including the western Mediterranean. They attain sizes up to 89 and $124 \mathrm{~cm}$ in length and 20 and $32 \mathrm{~kg}$ in weight, respectively. They are important commercially, with 110 (gray snapper) and 241 (crevalle jack) metric tons of commercial landing in US waters in 2008, and even more so as gamefishes, with 1188.4 (gray snapper) and 371 (crevalle jack) metric tons recreationally harvested in the same period (US National Marine Fisheries Service, pers. comm.). 


\section{MATERIALS AND METHODS}

Field sampling took place in early July of 2009, and was conducted as part of Florida Fish and Wildlife Research Institute (Florida Fish and Wildlife Conservation Commission) fisheries independent monitoring program. Fishes were captured with seine nets or otter trawls in shallow waters of Florida Bay within the legally protected boundaries of Everglades National Park (Fig. 1). Sample depths ranged from 0.7 to $1.6 \mathrm{~m}$, salinities from 25.8 to $41.8 \mathrm{psu}$, and temperatures from 27.7 to $32.4{ }^{\circ} \mathrm{C}$. Immediately after collection, fish were placed on ice and returned to the laboratory at the national park's Florida Bay Ranger Station and Science Center, in Key Largo, Florida.

Fish were examined macroscopically to detect infections of female nematodes. Scalpels, bone snips, and forceps were used to cut or tear host tissue away from parasites so that they could be collected gently with forceps or brushes. Specimens of Philometra brevispicula sp. $\mathrm{n}$. were detected by examination of buccal and branchial chambers and all specimens of Lutjanus griseus collected were checked for this parasite. The nematode species infecting crevalle jack were not necessarily visible externally and were not deliberately searched for until they were first detected. After these species were observed, subsequent host specimens were slit with a scalpel along dorsal, anal, and pectoral fin muscles, and skin from both flanks was pulled away from muscle to check for nematode specimens; only hosts that were examined by these means were considered for prevalence measurements. Hosts of female nematodes were checked for conspecific males by microscopic examination of tissues surrounding the female worms.

The recovered nematodes were washed in natural seawater or saline and then fixed in $70 \%$ ethanol or $5 \%$ phosphate-buffered formalin. In some cases, worms were straightened with hot water $\left(65-70^{\circ} \mathrm{C}\right)$ prior to fixation. For light microscopy (LM), nematodes were cleared with glycerine. Drawings were made with the aid of a Zeiss drawing attachment. After examination, the male holotype of $P$. brevispicula was mounted in glycerinejelly on a slide, whereas all other type and voucher specimens were stored in vials with $70 \%$ ethanol. Specimens examined via scanning electron microscopy (SEM) were postfixed in $1 \%$ osmium tetroxide (in phosphate buffer), dehydrated through a graded acetone series, critical-point-dried and sputter-coated with gold; they were examined using a JEOL JSM-7401F scanning electron microscope at an accelerating voltage of $4 \mathrm{kV} \mathrm{GB}$ low. All measurements are in micrometres unless otherwise indicated. The names of fishes follow Robins et al. (1991).

\section{RESULTS}

Philometridae Baylis et Daubney, 1926

\section{Philometra brevispicula $\mathrm{sp} . \mathrm{n}$.}

Figs. 2, 3

Male (1 specimen, holotype): Body filiform, whitish, $1.35 \mathrm{~mm}$ long, maximum width 24; width of cephalic end 16, of caudal end 16. Cuticle smooth. Cephalic end rounded. Mouth small, surrounded by indistinct cephalic papillae. Oesophagus 264 long (20\% of body length), with slightly outlined inflation at anterior end; posterior portion of oesophagus with well-developed, long oesophageal gland with large cell nucleus in middle.

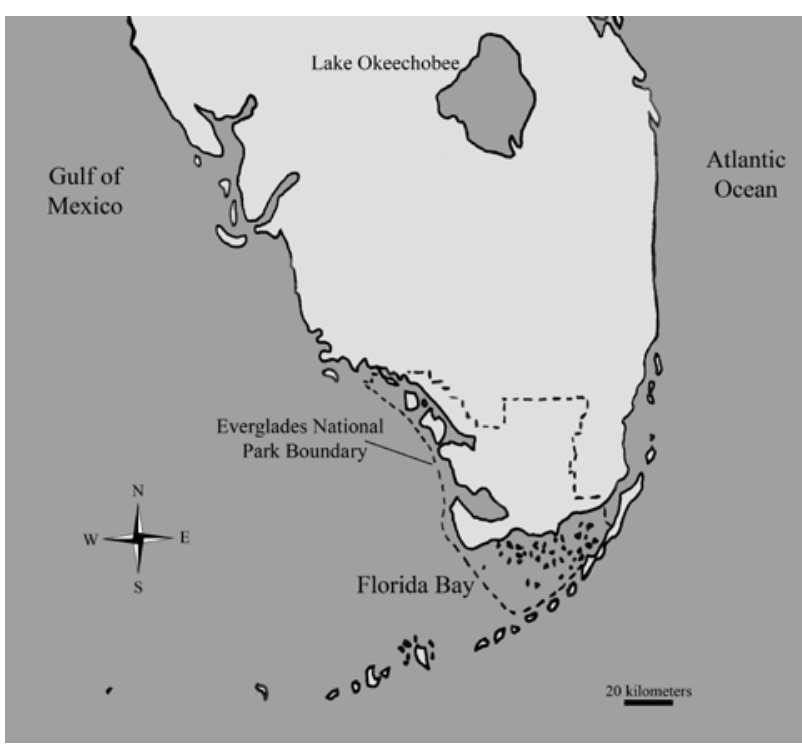

Fig. 1. Map of South Florida and Florida Bay showing study area (Everglades National Park - within dashed polygon) where specimens of Lutjanus griseus infected with Philometra brevispicula sp. n., and Caranx hippos infected with Philometroides grandipapillatus sp. n. and Caranginema americanum were collected.

Oesophageal nucleus and nerve ring 225 and 108, respectively, from anterior extremity (Fig. $2 \mathrm{H}$ ). Excretory pore 129 from anterior end of body. Small ventriculus measuring 3 in length and 7 in width. Testis reaching anteriorly to 258 from anterior extremity, slightly anterior to end of oesophagus (Fig. 2 H). Posterior end of body blunt, with broad, U-shaped, lobular mound and with one pair of preanal, one pair of adanal and one pair of postanal very flat and hardly visible caudal papillae (Fig. 2 I,J). Cloacal opening subterminal, tail 6 long. Spicules well sclerotized, slender, needle-like, equally long, with blunt proximal and sharply pointed distal tips; length of spicules 45 , representing 3\% of body length. Gubernaculum narrow, 39 long, without distinct dorsally bent proximal portion; distal tip of gubernaculum pointed, without distinct reflected dorsal barb (Fig. 2 I,J). Length ratio of gubernaculum and spicules 1:1.15.

Gravid female (5 specimens; measurements of allotype in parentheses): Body of fixed larvigerous specimens yellowish to brown-coloured, filiform, somewhat tapering at both ends; anterior end blunt, 995-163 (163) wide, with indistinct cephalic papillae in lateral view; posterior end rounded, 122-218 (204) wide. Cuticle smooth. Body length 28.41-43.96 (34.78) mm, maximum width 558816 (748); maximum width/length ratio of body 1:46-54 (1:46). Oral aperture large, oval, surrounded by 4 pairs of small submedian cephalic papillae of external circle and 6 single papillae (2 lateral and 4 submedian) of internal circle; lateral amphids slightly outlined (Figs. 2 C, 3 A,B). Bottom of mouth formed by flat surfaces of anterior ends 

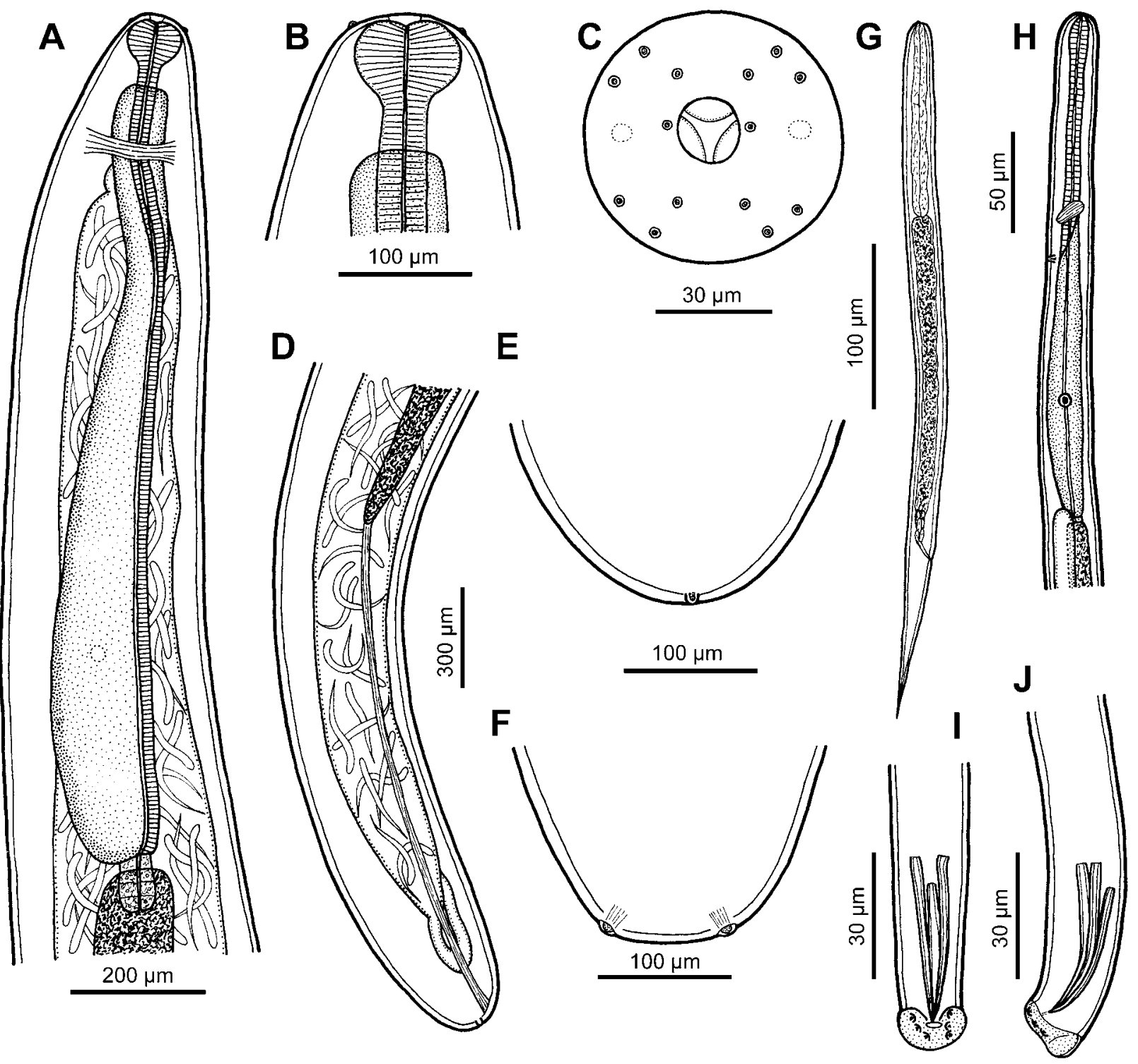

Fig. 2. Philometra brevispicula sp. n. A-F - gravid female (A - anterior end, lateral view; $\mathbf{B}, \mathbf{C}$ - cephalic end, lateral and apical views; D - posterior end, lateral view; $\mathbf{E}, \mathbf{F}$ - caudal end, lateral and dorsoventral views); $\mathbf{G}$ - larva from uterus; $\mathbf{H}-\mathbf{J}-$ male (Hanterior end, lateral view; I, J - posterior end, ventral and lateral views).

of three oesophageal sectors. Oesophagus narrow, swollen near mouth to form bulb 66-87 (87) long and 78-105 (105) wide, not separated from posterior cylindrical part of oesophagus (Fig. 2 B); oesophageal gland well developed, extending anteriorly far anterior to nerve ring, with poorly visible cell nucleus situated at its posterior part (Fig. 2 A). Overall length of oesophagus 1.20-1.73 (1.41) mm, representing 4 (4)\% of body length; width of muscular oesophagus just posterior to oesophageal bulb 41-68 (51), maximum width of oesophagus at its posterior portion, including gland, 95-177 (177). Small ventriculus 27-32 (27) long and 41-68 (51) wide, opening into intestine through valve. Nerve ring 204-258 (231) from anterior extremity. Intestine relatively narrow, brown-coloured, its posterior end atrophied, forming long translu- cent ligament attached ventrally to body wall near posterior extremity (Fig. 2 D); ligament 1.01-1.73 (1.66) $\mathrm{mm}$ long. Posterior end of body rounded, with pair of small subterminal caudal projections 3-6 (5) high (Fig. 2 E,F). Ovaries long, narrow, reflected. Uterus occupying major part of body, usually extending anteriorly nearly to level of nerve ring, posteriorly far posterior to end of intestine. Uterus filled with numerous elongate larvae 444-465 long and 18-19 wide $(\mathrm{n}=5)$; oesophagus $114-123$ long (26-28\% of body length), tail 99-105 long (22-24\% of body length), sharply pointed (Fig. $2 \mathrm{G}$ ).

Subgravid female (3 specimens): Body of fixed specimens yellowish to brown-coloured, 4.75-22.43 mm long, maximum width 163-462; maximum width/length ratio 1:29-49. Length of entire oesophagus $0.48-1.09 \mathrm{~mm}$ 
(5-10\% of body length), maximum width 30-95; anterior bulb 30-66 long, 33-84 wide. Nerve ring 102-177 from anterior extremity. Intestinal ligament 114-748 long. Uterus filled with numerous developing eggs.

Type host: Gray snapper, Lutjanus griseus (Lutjanidae, Perciformes) (range standard length 172-196 mm).

Sites of infection: Females occupied subcutaneous tissue in the mouth, often at the joint of the lower jaw (proximal articular). The male holotype was recovered from a pooled sample of masticated muscle and skin from inside the mouth of a host also infected with females, so the exact site of infection was not identified.

Ty p e 1 o c a 1 i t y : Florida Bay, Everglades National Park, Florida, USA $\left(25.2194^{\circ} \mathrm{N}, 80.4910^{\circ} \mathrm{W} ; 25.1955^{\circ} \mathrm{N}, 80.5719^{\circ} \mathrm{W}\right.$; $\left.25.2030^{\circ} \mathrm{N}, 80.5731^{\circ} \mathrm{W} ; 25.1638^{\circ} \mathrm{N}, 80.6802^{\circ} \mathrm{W}\right)$.

Prevalence and intensity: $25 \%$ (4 fish infected/ 16 fish examined); 1-10 specimens per fish.

Deposition of type specimens: Holotype (male), allotype (female) and 10 female paratypes (N-942) in the Helminthological Collection of the Institute of Parasitology, Biology Centre of the ASCR, České Budějovice, Czech Republic; 10 female paratypes (USNPC 102968) in the U.S. National Parasite Collection, Beltsville, Maryland, USA.

E t y mology: The specific name brevispicula (brevis $=$ short, spicula $=$ spicule) (a noun in apposition) relates to the characteristic feature of this species, i.e., unusually short spicules.

Remarks. The general morphology of philometrid specimens found in the mouth of Lutjanus griseus corresponds to the diagnosis of Philometra (see Rasheed 1963, Moravec 2006). Species of this genus, as well as those of other philometrid genera, exhibit a relatively high degree of host specificity (Rasheed 1963, Ivashkin et al. 1971, Moravec 2006, Quiazon et al. 2008a, b). In addition to morphological features, individual species are characterized by their location in the host, particularly that of gravid females (Moravec 2004, Moravec and Ali 2005, Moravec et al. 2006).

According to Moravec et al. (2009), there are 86 species of Philometra considered to be valid. However, an additional six congeneric species have been described since (Moravec and de Buron 2009a,b, Moravec and Justine 2009, Moravec et al. 2010, Moravec and Bakenhaster 2010). Consequently, at present this genus includes a total of 92 species. Of them, only 18 have the gravid females parasitic in the host's subcutaneous tissues, fins or the tissues of the buccal cavity, gill covers and gill arches.

However, six of the above-mentioned species were described from freshwater fishes (see Moravec 2006, Caspeta-Mandujano et al. 2009, Moravec et al. 2009). Only the following 12 species are parasites of marine (10) or brackish-water (2) fishes: Philometra beninensis Obiekezie, 1986, P. cynoscionis Moravec, de Buron et Roumillat, 2006, P. diplectri Moravec et Bakenhaster, 2010, P. kohnae Moravec et Rohde, 1992, P. lomi Moravec et Rohde, 1992, P. overstreeti Moravec et de Buron, 2006, P. pinnicola (Yamaguti, 1935), P. plotosi Moravec et Nagasawa,
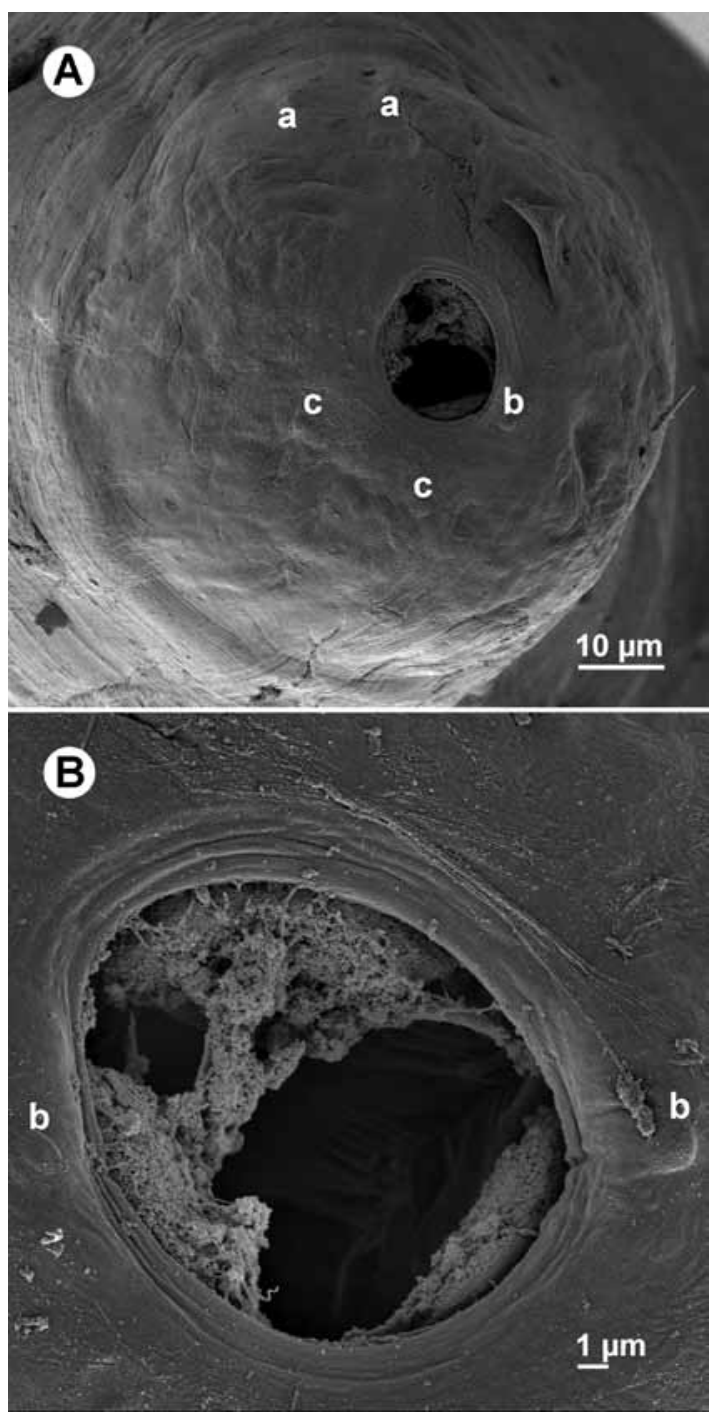

Fig. 3. Philometra brevispicula sp. n., scanning electron micrographs of gravid female. A - cephalic end, apical view; B - region of mouth, apical view. Abbreviations: a - cephalic papilla of external circle; $b$ - lateral cephalic papilla of internal circle; $\mathrm{c}$ - submedian cephalic papilla of internal circle.

1989, P. sebastodis Yamaguti, 1941, P. strongylurae Moravec et Ali, 2005, P. sydneyi Rasheed, 1963, and P. tylosuri Moravec et Ali, 2005. With the exception of $P$. diplectri, all these species are known only by females, whereas conspecific males have not yet been described.

Most of these species (P. kohnae, P. lomi, P. plotosi, $P$. sebastodis, $P$. strongylurae, $P$. sydneyi and $P$. tylosuri) are parasites of fishes belonging to Beloniformes, Scorpaeniformes, Siluriformes and one unidentified fish (reported as "white fish") in the Indian and Pacific Oceans (Yamaguti 1941, Rasheed 1963, Moravec and Nagasawa 1989, Moravec and Rohde 1992, Moravec and Ali 2005). Two species, $P$. beninensis and $P$. pinnicola, are reported from perciform fishes (Polydactylidae and Serranidae) from off the African Atlantic coast and off Japan, respectively (Yamaguti 1935, 1941, Obiekezie 1986, Obiekezie 
and Anders 1991, Obiekezie et al. 1992). Only three species were described from the western Atlantic Ocean, of which $P$. overstreeti and $P$. cynoscionis are parasites of the pleuronectiform fish Paralichthys lethostigma Jordan et Gilbert (Paralichthyidae) and the perciform fish Cynoscion nebulosus (Cuvier) (Sciaenidae) in brackishwaters (estuarine systems) of South Carolina and the Mississippi Sound, USA (Blaylock and Overstreet 1999, Moravec and de Buron 2006) and in estuarine systems of South Carolina (Moravec et al. 2006), respectively, whereas $P$. diplectri has recently been described from the marine perciform fish Diplectrum formosum (Linnaeus) (Serranidae) (Moravec and Bakenhaster 2010).

Philometra beninensis, P. cynoscionis, P. diplectri, $P$. kohnae, $P$. overstreeti and $P$. strongylurae can be distinguished from $P$. brevispicula, in addition to some other features, by markedly large (vs. small) cephalic papillae of the external circle in female, whereas P. lomi, P. plotosi, P. sebastodis and P. sydneyi by the absence of caudal projections (the last-named species also by the presence of conspicuous oesophageal teeth). The Japanese species $P$. pinnicola has smaller larvae (320-370 vs. 440-465) and no caudal projections were reported in it. Philometra tylosuri from Australian waters possesses distinct oesophageal teeth in contrast to the new species.

Of this group of Philometra spp., the male is known only for $P$. diplectri, the parasite of the serranid fish Diplectrum formosum in the Gulf of Mexico (Moravec and Bakenhaster 2010). The males of this species are 2.39-3.25 (vs. 1.35) $\mathrm{mm}$ long and their spicules measure 66-78 (vs. 45). In his unpublished Ph.D. thesis, GonzálezSolís (2001) described a single philometrid male (designated as Philometra sp. 4) collected from the fin of L. griseus in the southern Gulf of Mexico (off Celestún, Yucatán, Mexico). The spicules of this male were 35 and 36 long and it may well be that it was conspecific with P. brevispicula.

González-Solís et al. (2007) described another philometrid, Dentiphilometra lutjani González-Solís, Moravec et Tuz Paredes, 2007, based on gravid females found in the body musculature of the gray snapper Lutjanus griseus off the Caribbean coast of Mexico. Although the female morphology of this species is somewhat similar to that of $P$. brevispicula, both species differ considerably in the structure of the female mouth (presence vs. absence of a circumoral sclerotized ring armed with numerous small teeth). Moreover, in contrast to P. brevispicula, the oesophageal gland of $D$. lutjani extends anteriorly only to the level of the nerve ring (vs. extending considerably anterior to nerve ring), the caudal projections are large (vs. small), and the intestinal ligament is distinctly shorter (0.3 vs. $1.0-1.7 \mathrm{~mm})$.

Including Philometra brevispicula and the recently described $P$. diplectri, the fauna of Philometra spp. parasitizing marine and brackish-water fishes in the region of the western North Atlantic is to date represented by
16 nominal species. Philometra brevispicula is the second species of this genus recorded from a lutjanid fish. The only other species reported from snappers (Lutjanidae) is P. lateolabracis (Yamaguti, 1935) from the gonads of Lutjanus synagris (Linnaeus) and Lutjanus spp. in the western Atlantic (Bermuda, Cuba) (Rees 1970, Martínez and Ventosa 1982); however, considering the papers by Moravec (2008) and Quiazon et al. (2008a), this identification is questionable and, for the time being, these nematodes should be designated only as Philometra sp.

\section{Philometroides grandipapillatus sp. n. $\quad$ Figs. 4, 5}

Gravid female (3 specimens; measurements of holotype in parentheses): Body of fixed specimens whitish to yellow-brown, fairly short. Cuticle with small transparent, transversely oval, irregularly distributed inflations 3-9 (3-9) high (Figs. 4 E-G, 5 E,F); inflations more frequent on posterior half of body than on anterior one where they are sporadic; this ornamentation starts anteriorly near level of posterior end of oesophagus (Fig. 4 A,D). Length of body 20.45-44.72 (38.30) mm, maximum width 544-911 (911); anterior part of body somewhat broader than posterior part. Maximum width/length ratio 1:38-52 (1:42). Cephalic end blunt, markedly narrowed and angular at region of anterior oesophageal inflation, provided with conspicuously large cephalic papillae 18-27 (21) high (Fig. 4 A,B); this narrowed portion of body 68-82 (82) long and 150-190 (190) wide. Oral aperture almost circular. Bottom of mouth formed by flat surfaces of three oesophageal sectors. Cephalic papillae 14 in number, arranged in two circles. Papillae of external circle large, fleshy, oval-shaped in apical view, close to each other, with compressed sides, forming thus a dorsal and ventral transverse cephalic mound; each of these two mounds consisting of four papillae (dorso-lateral papillae distinctly smaller than dorso- and ventro-submedian papillae). Papillae of internal circle very small, represented by four single submedian papillae and two lateral papillae surrounding oral aperture (Figs. $4 \mathrm{C}, 5 \mathrm{~A}-\mathrm{C}$ ). Oesophagus muscular, forming distinct bulb at anterior end, with large oesophageal gland extending from level of nerve ring to end of oesophagus, possessing difficult to observe cell nucleus at its middle; oesophagus including bulb 1.071.92 (1.92) mm long, representing 4-5 (5)\% of body length; anterior bulb 54-90 (90) long and 90-123 (123) wide. Small ventriculus 27-41 (41) long and 54-82 (82) wide, opening into intestine through valve (Fig. 4 A). Intestine light-brown, straight, displaced laterally by uterus; anterior end of intestine narrow, posterior end atrophied, forming ligament attached ventrally to body wall near posterior extremity (Fig. 4 D). Posterior end of body somewhat narrowed, rounded, with several irregularly scattered cuticular bosses; no caudal projections present (Figs. 4 I, $5 \mathrm{D})$. Vulva and vagina absent. Ovaries reflected, situated near anterior and posterior ends of body; anterior ovary reaching anteriorly to level of nerve ring, posterior ovary 

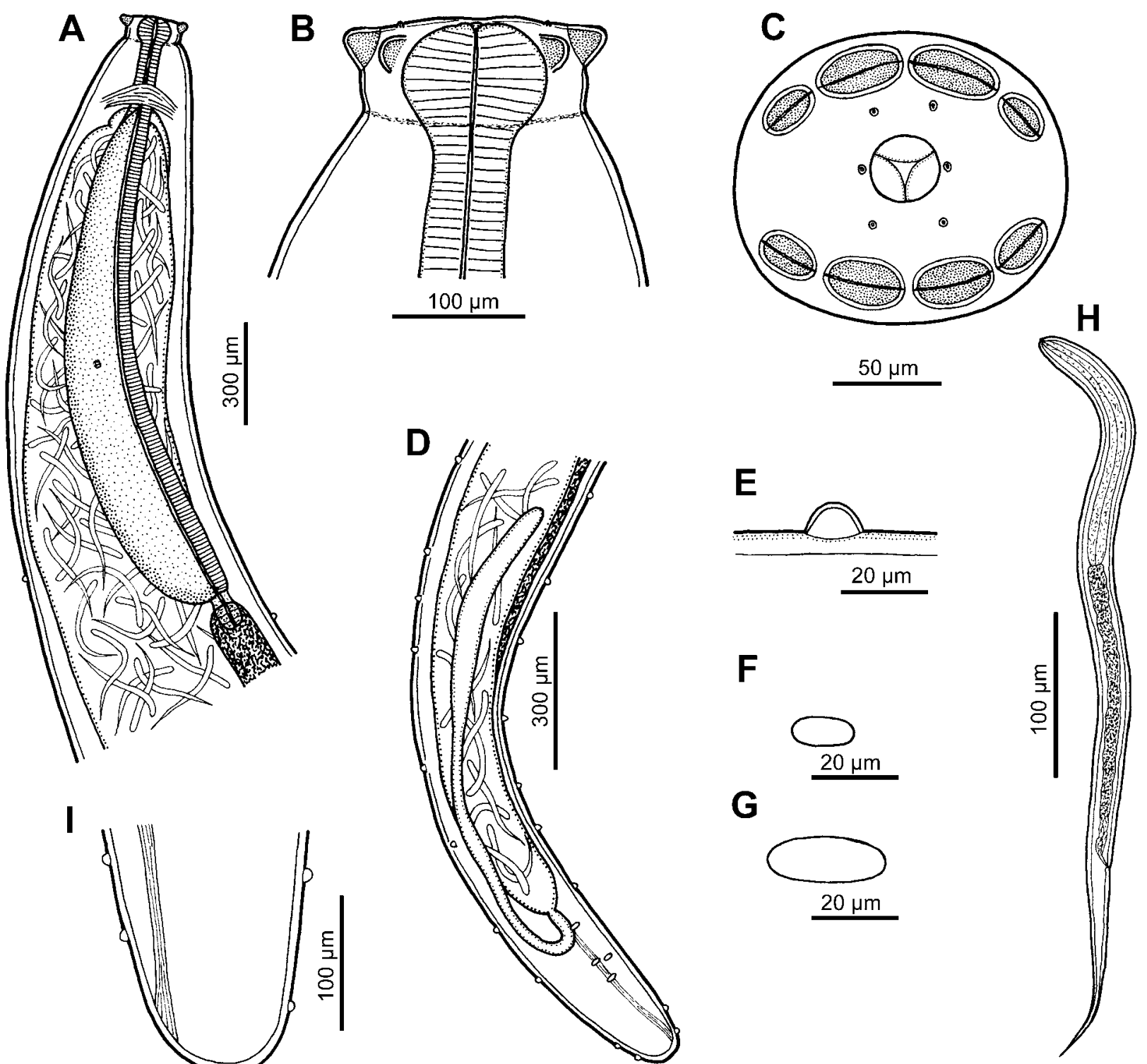

Fig. 4. Philometroides grandipapillatus sp. n., gravid female. A - anterior end, lateral view; B, C - cephalic end, lateral and apical views; D - posterior end, lateral view; $\mathbf{E}$ - cuticular inflation, lateral view; $\mathbf{F}, \mathbf{G}$ - cuticular inflations, apical views; $\mathbf{H}$ - larva from uterus; I - caudal end, lateral view.

posteriorly to level of intestinal ligament (Fig. 4 D). Uterus occupying most space in body, filled with larvae and eggs. Larvae $(\mathrm{n}=10)$ slender, 441-474 long, maximum width 15-18; oesophagus 114-135, representing 26-29\% of body length; tail sharply pointed, 114-129 long, representing 24-28\% of body length (Fig. $4 \mathrm{H}$ ).

Male: Unknown.

Type host: Crevalle jack, Caranx hippos (Carangidae, Perciformes) (standard length $154 \mathrm{~mm}$ ).

Site of infection: Although partially visible beneath the skin at the pectoral fin base, worms primarily occupied the muscle associated with the pectoral girdle (scapula, coracoid, and cleithrum).
Type locality: Florida Bay, Everglades National Park, Florida, USA $\left(25.1955^{\circ} \mathrm{N}, 80.5719^{\circ} \mathrm{W}\right)$.

Prevalence and intensity: 1 fish infected/7 fish examined; 3 specimens.

Deposition of type specimens: Holotype (N-943) in the Helminthological Collection of the Institute of Parasitology, Biology Centre of the ASCR, České Budějovice, Czech Republic; 1 paratype (USNPC 102973) in the U.S. National Parasite Collection, Beltsville, Maryland, USA.

Etymology: The specific name grandipapillatus (grandis $=$ large, papillatus $=$ papillate) (adjective) relates to the characteristic feature of this species, i.e., markedly large cephalic papillae of the external circle. 


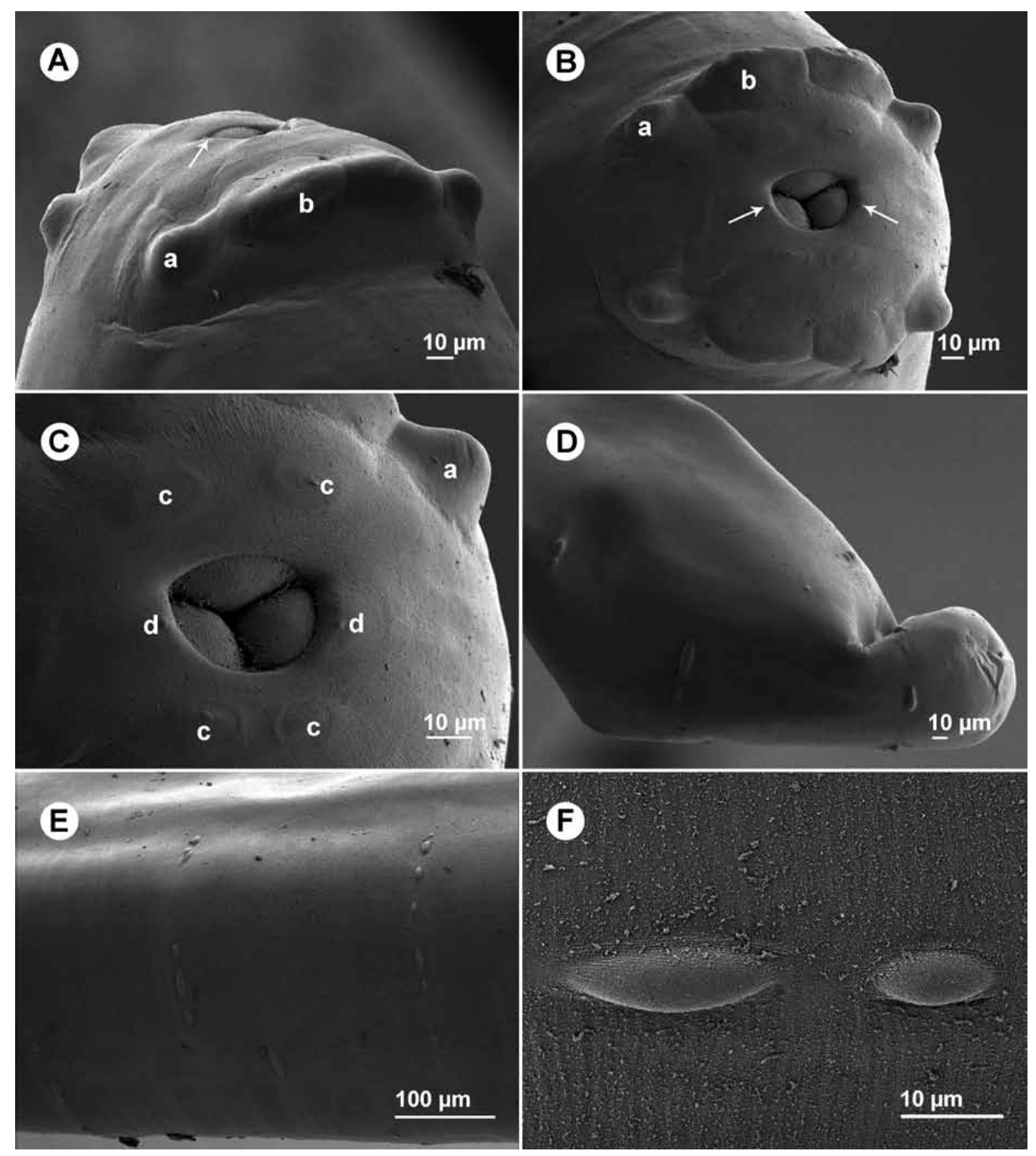

Fig. 5. Philometroides grandipapillatus sp. n., scanning electron micrographs of gravid female. A, B - cephalic end, subdorsal and apical views (arrows indicate lateral papillae of internal circle); C - region of oral aperture, apical view; D - caudal end, lateral view; E, F - cuticular ornamentations on middle part of body, apical views. Abbreviations: a - smaller cephalic papilla of external circle; $\mathrm{b}$ - larger cephalic papilla of external circle; $\mathrm{c}$ - submedian cephalic papilla of internal circle; $\mathrm{d}$ - lateral papilla of internal circle.

Remarks. By the general morphology, in particular the presence of numerous irregular excrescences on the cuticle of gravid female, the specimens of the present material may be assigned to Philometroides (see Rasheed 1963, Moravec 2006). Moravec and de Buron (2009a) reported 26 valid species in this genus, however, one of them (P. hydrocyoni Fahmy, Mandour et El-Nafar, 1976) has recently been transferred to the newly established genus Afrophilometra Moravec, Charo-Karisa et Jirků, 2009 (see Moravec et al. 2009). Most species of Philometroides were described only from females, whereas conspecific males are known for 8 species. The majority of them (19) occur in freshwater fishes, whereas 5 were described from marine fishes and 1 from a brackish-water fish. 
By the narrow cephalic region markedly protruding out from the remaining part of body, the number and arrangement of cephalic papillae of the external circle and the absence of caudal projections in gravid female, Philometroides grandipapillatus is similar only to $P$. atropi (Parukhin, 1966). The latter species is also the parasite of carangid fishes, Atropus atropos (Bloch et Schneider) and Selar crumenophthalmus (Bloch), distributed in the South China Sea, the Gulf of Tonkin near Vietnam and the Red Sea (Parukhin 1966a,b, 1971). However, it differs from P. grandipapillatus mainly in having only small cephalic papillae, the oesophagus without an anterior bulbous inflation, and in the shape of cuticular ornamentations (circular vs. transverse-oval). Moreover, in contrast to the new species, the site of infection of $P$. atropi is the abdominal cavity and, sometimes, the stomach wall.

In possessing eight markedly large cephalic papillae and transversely elongated cuticular ornamentations, and in lacking caudal projections in gravid female, $P h i-$ lometroides grandipapillatus also somewhat resembles P. paralichthydis Moravec et de Buron, 2006, a parasite of the subcutaneous tissues of mouth and head, and fins of the brackish-water pleuronectiform fish (southern flounder) Paralichthys lethostigma Jordan et Gilbert in some estuarine systems in the USA (Moravec and de Buron 2006). However, in contrast to the new species, the cephalic end of $P$. paralichthydis is not conspicuously narrowed and its structure is different, cephalic papillae of the internal circle are absent, and the anterior bulbous inflation of the oesophagus is markedly large.

Of other species of Philometroides parasitizing subcutaneous tissues of the host, only two, $P$. pseudorasbori Wang, Yu et Wu, 1995 and P. strelkovi Vismanis et Yunchis, 1994, both parasites of freshwater cyprinids in East Asia (China and Russian Far East) (Vismanis and Yunchis 1994, Wang et al. 1995, Moravec 2006), possess eight large cephalic papillae as does $P$. grandipapillatus. However, they differ in that they have well-developed caudal projections, circular cuticular ornamentations and dome-shaped cephalic ends. In having a markedly narrowed, angular cephalic end and transversely elongated cuticular excrescences, $P$. grandipapillatus is very similar to $P$. dogieli Vismanis et Yukhimenko, 1974 from the fins of the freshwater cyprinid Elopichthys bambusa (Richardson) from East Asia (Russian Far East) (Vismanis and Yukhimenko 1974), but only six "pronounced cephalic outgrowths" (papillae?) are reported in its original description. However, the cephalic end of $P$. dogieli was studied only in a lateral view, so that the actual number of external cephalic papillae might be eight as in the majority of other philometrids. In contrast to $P$. grandipapillatus, gravid females of $P$. dogieli possess well-developed caudal projections.

The general morphology of Philometroides grandipapillatus, especially the narrowed angular cephalic end of gravid female, also resembles that of Paraphilometroides nemipteri Moravec et Shaharom-Harrison,1989, the typeand the only species of Paraphilometroides Moravec et Shaharom-Harrison, 1989, which was described from females found in the fins and operculum of Nemipterus peronii (Valenciennes) (Nemipteridae, Perciformes) from the South China Sea off Malaysia (Moravec and Shaharom-Harrison 1989). Recent SEM study of the latter species (Moravec 2010) confirmed the validity of Paraphilometroides, which differs from Philometroides mainly in that the cephalic papillae of the external circle are fused together to form a dorsal and a ventral cephalic ala bent into a curve; transverse-oval cuticular ornamentations were also found on females of $P$. nemipteri.

Philometroides grandipapillatus is the sixth species of this genus described from a marine fish and the second one reported from marine fishes of the western Atlantic Ocean [besides P. marinus Moravec et de Buron, 2009 from Rachycentron canadum (Linnaeus) off South Carolina, USA]. Whereas other species of Philometroides from marine fishes are parasitic in the host's abdominal cavity (P. atropi, P. denticulatus Rasheed, 1965, P. mari$n u s)$, or in the eyes and orbits (P. oveni Parukhin, 1975), only $P$. grandipapillatus and $P$. seriolae (Ishii, 1931) occupy muscle tissue. Besides $P$. atropi from the Pacific and Indian Oceans (see above) and P. seriolae from Seriola quinqueradiata Temminck et Schlegel from the Pacific Ocean (off Japan), it is the third species of Philometroides described from fishes of the family Carangidae.

\section{Caranginema americanum Moravec, Montoya-} Mendoza et Salgado-Maldonado, 2008

Nongravid female (1 large complete specimen and body fragments of 3 smaller specimens): Body length of complete specimen $193 \mathrm{~mm}$, maximum width 775; width of cephalic end 225, of caudal end 177; oesophageal teeth 18 high. Maximum width/length ratio 1:249. Entire oesophagus $1.66 \mathrm{~mm}$ long, representing $0.9 \%$ of body length. Nerve ring 449 from anterior extremity. Supposed body lengths of fragmented specimens 75,40 and $35 \mathrm{~mm}$.

Host: Crevalle jack, Caranx hippos (Carangidae, Perciformes).

Site of infection: Subcutaneous fascia of trunk muscle, especially between the carinatus dorsalis and ventralis muscles and the radial levator and flexor muscles of the dorsal and anal fins, respectively. Also observed pre-caudally in fascia at the abutment of hypaxial and epaxial lateral myomeres under the lateral line. Occasionally passing through muscle and between pterygiophores from one side of the body to the other. In one instance, protruding through the skin near the dorsal fin with more than $5 \mathrm{~mm}$ of worm exposed to the environment (possibly to release larvae). Subcutaneous migration tracks associated with this species were common at various sites on flanks of infected hosts.

L o c a lities: Florida Bay, Everglades National Park, Flori$\mathrm{da}$, USA $\left(25.2256^{\circ} \mathrm{N}, 80.4517^{\circ} \mathrm{W} ; 25.1955^{\circ} \mathrm{N}, 80.5719^{\circ} \mathrm{W}\right.$; 
$\left.25.1090^{\circ} \mathrm{N}, 80.6543^{\circ} \mathrm{W} ; 25.1025^{\circ} \mathrm{N}, 80.6457^{\circ} \mathrm{W}\right)$. Previously reported from the coral reef Arrecife El Cabezo, southern Gulf of Mexico, Veracruz, Mexico (type locality) (Moravec et al. 2008b).

Prevalence and intensity: 6 fish infected/9 fish examined; $1-5$ specimens.

Deposition of voucher specimens: One complete specimen (USNPC 102974) in the U.S. National Parasite Collection, Beltsville, Maryland, USA; 3 body fragments $(\mathrm{N}-892)$ in the Helminthological Collection of the Institute of Parasitology, Biology Centre of the ASCR, České Budějovice, Czech Republic.

Remarks. Only a complete, nongravid female of this species was examined, whose morphology is in a full agreement with the original description of Caranginema americanum given by Moravec et al. (2008b). This species is the only representative of the recently erected monotypic genus Caranginema and it was described solely from females found in the subcutaneous tissues of Caranx hippos from a coral reef in the southern Gulf of Mexico, Veracruz, Mexico (Moravec et al. 2008b). The present finding of this nematode in the same fish species in waters of Florida, USA indicates that this parasite is widespread in the Gulf of Mexico.
Acknowledgements. We thank our colleagues at the Florida Fish and Wildlife Conservation Commission's Fish and Wildlife Research Institute (FWRI) in the Fisheries Independent Monitoring Program (FIM) and the Fish and Wildlife Health group (FWH). Kerry Flaherty and Ed Matheson (FIM) worked on our behalf with the National Parks Service to accommodate and permit our sampling efforts, and shared their project data. Maki Tabuchi and Yasu Kiryu (FWH) assisted with parasite collection. Howard Brown (FWH) assisted with production of Fig. 1. We also wish to thank the staff of the Laboratory of Electron Microscopy, Institute of Parasitology, Biology Centre of the Academy of Sciences of the Czech Republic, České Budějovice for technical assistance, and Blanka Škoríková, Department of Helminthology at the same institute, for help with illustrations. This study was partly supported by the research projects of the Institute of Parasitology, BC ASCR (Z60220518 and LC522). Fish collection was funded through the United States Department of the Interior National Park Service, Study No. EVER-00272; Permit No. EVER-2007-SCI-0079. Parasite collection was supported in part by proceeds from the state of Florida saltwater recreational fishing licenses and by funding from the Department of the Interior, U.S. Fish and Wildlife Service, Federal Aid for Sportfish Restoration Grant number F-72. The views and conclusions contained in this document are those of the authors and should not be interpreted as representing the opinions or policies of the U.S. Government. Mention of trade names or commercial products does not constitute their endorsement by the U.S. Government.

\section{REFERENCES}

Blaylock R.B., Overstreet R.M. 1999: Margolisianum bulbosum n. gen., n. sp. (Nematoda: Philometridae) from the southern flounder, Paralichthys lethostigma (Pisces: Bothidae), in Mississippi Sound, USA. J. Parasitol. 85: 306-312.

Caspeta-Mandujano J.M., Granados Ramírez J.G., PeraltaRodríguez J.L. 2009: A new philometrid species (Nematoda) from the freshwater fish Cichlasoma istlanum (Jordan and Snyder, 1899) (Cichlidae) in Mexico. J. Parasitol. 95: 403-406.

Froese R., Pauly D. (Eds.) 2010: FishBase. World Wide Web electronic publication, www.fishbase.org, 03/2010.

GonZÁlez-Solís D. 2001: Nematodes (Nematoda) as the parasites of fishes in the conditions of southern Mexico. Ph.D. thesis. Institute of Parasitology, Academy of Sciences of the Czech Republic, České Budějovice, Czech Republic, $152 \mathrm{pp}$.

González-Solís D., Moravec F., Tuz Paredes V.M. 2007: A new species of Dentiphilometra (Nematoda: Philometridae) from the musculature of the gray snapper Lutjanus griseus (Osteichthyes) off the Caribbean coast of Mexico. J. Parasitol. 93: $1132-1135$

Ivashrin V.M., Sobolev A.A., Khromova L.A. 1971: [Camallanata of Animals and Man and the Diseases Caused by Them.] Osnovy Nematodologii 22. Nauka, Moscow, 388 pp. (In Russian.)

Martínez J.J., Ventosa L. 1982: Philometra lateolabracis (Nematoda: Philometridae), parásito de la biajaiba (Lutjanus synagris) (Osteichthyes: Lutjanidae) de Cuba. Poeyana 248: 1-6.

Moravec F. 2004: Some aspects of the taxonomy and biology of dracunculoid nematodes parasitic in fishes: a review. Folia Parasitol. 51: 1-13.

Moravec F. 2006: Dracunculoid and Anguillicoloid Nematodes Parasitic in Vertebrates. Academia, Prague, 634 pp.
Moravec F. 2008: Systematic status of Philometra jordanoi (López-Neyra, 1951) and some other congeneric species previously identified as Philometra lateolabracis (Yamaguti, 1935) (Nematoda: Philometridae). Folia Parasitol. 55: 159-160.

Moravec F. 2010: New data on the morphology of Paraphilometroides nemipteri (Nematoda: Philometridae), as revealed by SEM. Folia Parasitol. (In press.)

Moravec F., Ali A.H. 2005: Two new species of Philometra (Nematoda: Philometridae) from needlefishes (Belonidae) in Iraq, with a key to Philometra spp. parasitic in the host's subcutaneous tissue, fins and musculature. Folia Parasitol. 52: 267-273.

Moravec F., Bakenhaster M. 2010: A new species of Philometra (Nematoda: Philometridae) from the sand seabass Diplectrum formosum (Serranidae) off Florida, northern Gulf of Mexico. J. Parasitol. (In press.)

Moravec F., Charo-Karisa H., JirkU゚ M. 2009: Philometrids (Nematoda: Philometridae) from fishes of Lake Turkana, Kenya, including two new species of Philometra and erection of Afrophilometra gen. n. Folia Parasitol. 56: 41-54.

Moravec F., De Buron I. 2006: Two new species of philometrid nematodes (Nematoda: Philometridae) from the southern flounder Paralichthys lethostigma in the estuaries of South Carolina, USA. Folia Parasitol. 53: 139-146.

Moravec F., De Buron I. 2009a: Two new species of philometrids (Nematoda: Philometridae) from marine fishes off South Carolina. J. Parasitol. 95: 722-727.

Moravec F., De Buron I. 2009b: New data on three gonad-infecting species of Philometra (Nematoda, Philometridae) from estuarine fishes in South Carolina, USA. Acta Parasitol. 54: 244-252. 
Moravec F., de Buron I., Baker T.G., González-Solís D. 2008a: Some gonad-infecting species of Philometra (Nematoda, Philometridae) from offshore fishes of South Carolina and Georgia, USA, including Philometra charlestonensis sp. nov. from the scamp Mycteroperca phenax. Acta Parasitol. 53: 382-391.

Moravec F., de Buron I., Roumillat W.A. 2006: Two new species of Philometra (Nematoda: Philometridae) parasitic in the perciform fish Cynoscion nebulosus (Sciaenidae) in the estuaries of South Carolina, USA. Folia Parasitol. 53: 63-70.

Moravec F., Fajer-Avila E.J., Bakenhaster M. 2010: Philometra floridensis sp. n. (Nematoda: Philometridae) from the ovary of the red drum Sciaenops ocellatus (Osteichthyes: Sciaenidae) off Florida, USA. J. Helminthol. 84: 49-54.

Moravec F., Justine J.-L. 2009: New data on dracunculoid nematodes from fishes off New Caledonia, including four new species of Philometra (Philometridae) and Ichthyofilaria (Guyanemidae). Folia Parasitol. 56: 129-142.

Moravec F., Montoya-Mendoza J., Salgado-Maldonado G. 2008b: A new genus and species of philometrid (Nematoda) from the subcutaneous tissue of the crevalle jack, Caranx hippos (Osteichthyes), from the southern Gulf of Mexico. J. Parasitol. 94: 1346-1350.

Moravec F., Nagasawa K. 1989: Observations on some nematodes parasitic in Japanese freshwater fishes. Folia Parasitol. 36: 127-141

Moravec F., Rohde K. 1992: Three species of nematodes of the superfamily Dracunculoidea from Australian fishes. Acta Soc. Zool. Bohemoslov. 56: 187-195.

Moravec F., Salgado-Maldonado G. 2007: A new species of Philometra (Nematoda, Philometridae) from the gonads of the rock hind Epinephelus adscensionis (Osteichthyes) from the southern Gulf of Mexico. Acta Parasitol. 52: 376-381.

Moravec F., Santana-Piñeros A.M., González-Solís D., Torres-Huerta A.M. 2007: A new species of Spirophilometra (Nematoda: Philometridae) from the yellowfin snook Centropomus robalito (Osteichthyes) in southern Mexico. Folia Parasitol. 54: 215-219.

Moravec F., Shaharom-Harrison F. 1989: Paraphilometroides nemipteri gen. et sp. n. (Nematoda: Philometridae) from the marine fish Nemipterus peronii (Valenciennes) from Malaysia. Folia Parasitol. 36: 345-350.

National Marine Fisheries Service, Fisheries Statistics Division (personal communication), http://www.st.nmfs.noaa.gov/ st1/index.html Feb, 2010.

OBiekezie A.I. 1986: Philometra (Ranjhinema) beninensis sp. nov. (Nematoda: Philometridae) from the giant African threadfin, Polydactylus quadrifiliis Cuvier, 1829 (Teleostei: Polynemidae). Rev. Zool. Afr. 100: 357-361.

Obiekezie A.I., Anders K. 1991: Scanning electron microscope studies on Philometra (Ranjhinema) beninensis Obiekezie, 1986 (Nematoda: Philometridae). Folia Parasitol. 38: 371-374.

Received 11 March 2010
Obiekezie A.I., Anders K., Lick R., Möller H., Palm H. 1992: External lesions and flesh parasites in commercial fishes of $\mathrm{Ni}$ gerian inshore waters. Aquat. Living Resour. 5: 173-183.

Parukhin A.M. 1966a: Pseudophilometroides atropi gen. et sp. n., a new nematode of the family Dracunculidae Leiper, 1912. Zool. Zh. 45: 766-767. (In Russian, Engl. summary.)

Parukhin A.M. 1966b: Studies on the helminth fauna of fishes of the family Carangidae from the South China Sea. In: S.L. Delyamure (Ed.), Gel'mintofauna Zhivotnykh Yuzhnykh Morey. Biologiya Morya. Naukova Dumka, Kiev, pp. 80-96. (In Russian.)

Parukhin A.M. 1971: Nematodes from fishes of the Red Sea and Indian Ocean. In: S.L. Delyamure (Ed.), Voprosy Ekologii Ryb Yuzhnykh Morey. Biologiya Morya 23. Naukova Dumka, Kiev, pp. 177-193. (In Russian.)

Petter A.-J., Radujković B.M. 1989: Parasites des poissons marins du Montenegro: Nematodes. Acta Adriatica 30: 195236.

Quiazon K.M.A., Yoshinaga T., Ogawa K. 2008a: Taxonomical study into two new species of Philometra (Nematoda: Philometridae) previously identified as Philometra lateolabracis (Yamaguti, 1935). Folia Parasitol. 55: 29-41.

Quiazon K.M.A., Yoshinaga T., Ogawa K. 2008b: Philometra sawara $\mathrm{sp} . \mathrm{n}$. and a redescription of Philometra sciaenae Yamaguti, 1941 and Philometra nemipteri Luo, 2001 (Nematoda: Philometridae): a morphological and molecular approach. Folia Parasitol. 55: 277-290.

Rasheed S. 1963: A revision of the genus Philometra Costa, 1845. J. Helminthol. 37: 89-130.

Rees G. 1970: Some helminth parasites of fishes of Bermuda and an account of the attachment organ of Alcicornis carangis MacCallum, 1917 (Digenea: Bucephalidae). Parasitology 60: 195-221.

Robins R.C., Reeve M.B., Bond C.E., Brooker J.R., Lachner E.A., Lea R.N., Scott W.B. 1991: Common and Scientific Names of Fishes From the United States and Canada. American Fisheries Society Special Publication 20. American Fisheries Society, Bethesda, Maryland, 183 pp.

Vismanis K.O., Yukhimenko S.S. 1974: On the morphology of Philometroides dogieli sp. n. (Nematoda, Philometridae) from the fins of Elopichthys bambusa. Parazitologiya 8: 53-56. (In Russian.)

Vismanis K.O., Yunchis O. 1994: Two new fish nematode species of the genus Philometroides (Nematoda, Philometridae), found in Lake Khanka and the River Amur, Russia. Proc. Latvian Acad. Sci., Sect. B, No. 5/6: 113-116.

Wang D., Yu Y., Wu H. 1995: Studies on the philometroidosis of grass carp (Ctenopharyngodon idellus). Trans. Res. Fish Dis. 2: 121-125 + Pl. 15. (In Chinese, Engl. summary.)

Yamaguti S. 1935: Studies on the helminth fauna of Japan. Part 9. Nematodes of fishes, 1. Jpn. J. Zool. 6: 337-386.

Yamaguti S. 1941: Studies on the helminth fauna of Japan. Part 33. II. Nematodes of fishes. Jpn. J. Zool. 9: 343-396.

Accepted 30 April 2010 